\title{
Social Network Analysis on the Driver Partner Application for Home Culinary Entrepreneurs
}

\author{
Wahyu Nurul Faroh ${ }^{1 *}$, Sri Eka Lestari ${ }^{2}$ \\ ${ }^{1,2}$ Department of Management, Faculty of Economic, Pamulang University \\ ${ }^{*}$ Corresponding author: \\ Email: dosen01061@unpam.ac.id
}

\begin{abstract}
.
Technology implementation is becoming more prevalent nowadays. This, of course, makes it easier for entrepreneurs in marketing, sales, and the ease of establishing communication with potential buyers. However, it is not automatically able to be fully utilized. There are still many entrepreneurs who know about it but do not know-how and use it to increase sales. For this reason, this study will analyze how the effectiveness of using a simple application, which involves driver-partners in maximizing sales. This research will begin by crawling data on social networks, then withdrawing data from social network importers using Gephi, and then analyzing it using Social Network Analysis.The result shows that home-based culinary entrepreneurs have to collaborate with driver-partner applications to increase sales, brand awareness, and impressions to consumers.
\end{abstract}

Keywords: Driver Partner Application, Social Network Analysis, Small and Medium Enterprises

\section{INTRODUCTION}

Of the many entrepreneurs, only a few are using Information Technology (IT) to run their business. This is due to the entrepreneur's lack of IT understanding, limited investment, and lack of support from the government [1]. Furthermore, the absence of previous experience, low education, low skills, and age also causes a lack of utilizing IT [2]. Many of these factors make it difficult for them to develop their business. Even though, IT is a change that we cannot afford. If an entrepreneur does not keep up with changes, the changes themselves will erode themselves. As is done by the younger generation today, it dominates the use of technology in the era of disruption [3].

The phenomenon of online motorcycle taxi itself, as a form of IT implementation, is growing rapidly. As there are many driver-partners (the name for online motorcycle taxi drivers), this is in line with the number of business entrepreneurs. According to Gojek Co-CEO Andre Soelistyo, at the age of 10, Gojek has more than 2 million partners throughout Southeast Asia [4]. In addition, the culinary business is a growing business sector. The food and beverage industry that is able to grow positively in the second quarter of 2020 after being depressed due to the impact of the Covid-19 pandemic. Based on data from the Central Statistics Agency (BPS), in the second quarter-2020, the food and beverage industry grew by 0.22 
percent annually [5]. Therefore, researchers need to find out more about the factors that can influence entrepreneurs to want to implement IT, especially: simple existing applications. The driver-partner application for the existing and superior culinary business is GoFood or GrabFood, which has run culinary delivery services by utilizing the services of a driver-partner. This means positioning entrepreneurs to be able to make friends with existing changes, especially IT. When IT is implemented, the application of technology will increase the income of entrepreneurs [6, 7].

Home culinary entrepreneurs often come into contact with issues of promotion, time management (raising children), and delivery. The emergence of the GoFood and GrabFood applications alleviates these problems; thus, they can be avoided. However, not all home culinary entrepreneurs know, are aware, and understand the use of these applications. This causes their income to be limited to the surrounding environment. But when implementing GoFood and GrabFood applications, the marketing will expand and, the income will increase.

Entrepreneurs in Indonesia should always be supported by the Government. After the economic crisis of 1997-1998, the number of SMEs in Indonesia continued to increase to reach 57.8 million units in 2013. During that 15 -year period, the number of SMEs increased by 46 percent. BPS data shows that SMEs are able to absorb 117 million workers or 97 percent of labor absorption in 2018 [8]. Moreover, Chairman of the Indonesian Micro, Small and Medium Enterprises Association (Akumindo) Ikhsan Ingratubun said, with a consistent estimate of SMEs growth, his party believes that the total contribution to GDP by 2020 can reach 65 percent or about Rp 2,394.5 trillion. Though the year of realization of SMEs' contribution to GDP last year reached 60.34 percent [9]. So the role of entrepreneurs in the country's economy is seen.bStarting from this thought, the researcher felt the need to research the Utilization of the Driver Partner Application to maximize the Home Culinary Entrepreneur's Business.

\section{METHODS}

This research is a descriptive study, which aims to explain by describing the characteristics of objects, groups, people, organizations that describe certain conditions and situations. This research uses Social Network Analysis method. Social Network Analysis describes social relationships consisting of nodes, actors or individuals who are in the network under study, and links, the relationships between these actors [10]. In this study, standard measurements (properties) were used in the table 1.

Table 1. Measurement standards

\begin{tabular}{|l|l|}
\hline Index & Characteristics \\
\hline Density & The ratio of existing ties to all possible connections \\
\hline Inclusiveness & $\begin{array}{l}\text { The number of points connected is expressed as a } \\
\text { proportion of the total number of points }\end{array}$ \\
\hline Average Degree & The number of connections (links) associated with each \\
\hline
\end{tabular}




\begin{tabular}{|l|l|}
\hline & actor (nodes) in social networks. \\
\hline $\begin{array}{l}\text { Clustering } \\
\text { Cenficient }\end{array}$ & $\begin{array}{l}\text { A measure of the extent to which actors (nodes) in a } \\
\text { network tend to cluster together }\end{array}$ \\
\hline Page Rank & $\begin{array}{l}\text { Network index that measures the degree of dispersion } \\
\text { of all node centrality scores in the network from the } \\
\text { maximum centrality score obtained in the network. } \\
\text { Centrality measures the number of connections (links) } \\
\text { that occur to actors (nodes) }\end{array}$ \\
$\begin{array}{l}\text { The essential point of articulation between the elements } \\
\text { that make up the components. This suggests some kind } \\
\text { of local centrality, and the absence of PageRank } \\
\text { implies that communication and exchanges among } \\
\text { component members are independent of one member. }\end{array}$ \\
\hline
\end{tabular}

Meanwhile, to get this research data, we do data crawling and streaming importers on social networks. The network data collected is obtained through the online streaming Gephi analysis tool. The data itself will be divided into three parts to collect relational data and actor attributes. This data will provide information that can be used as a typology of actors involved in this network. So the network typology to be built can be described on Fig 1.

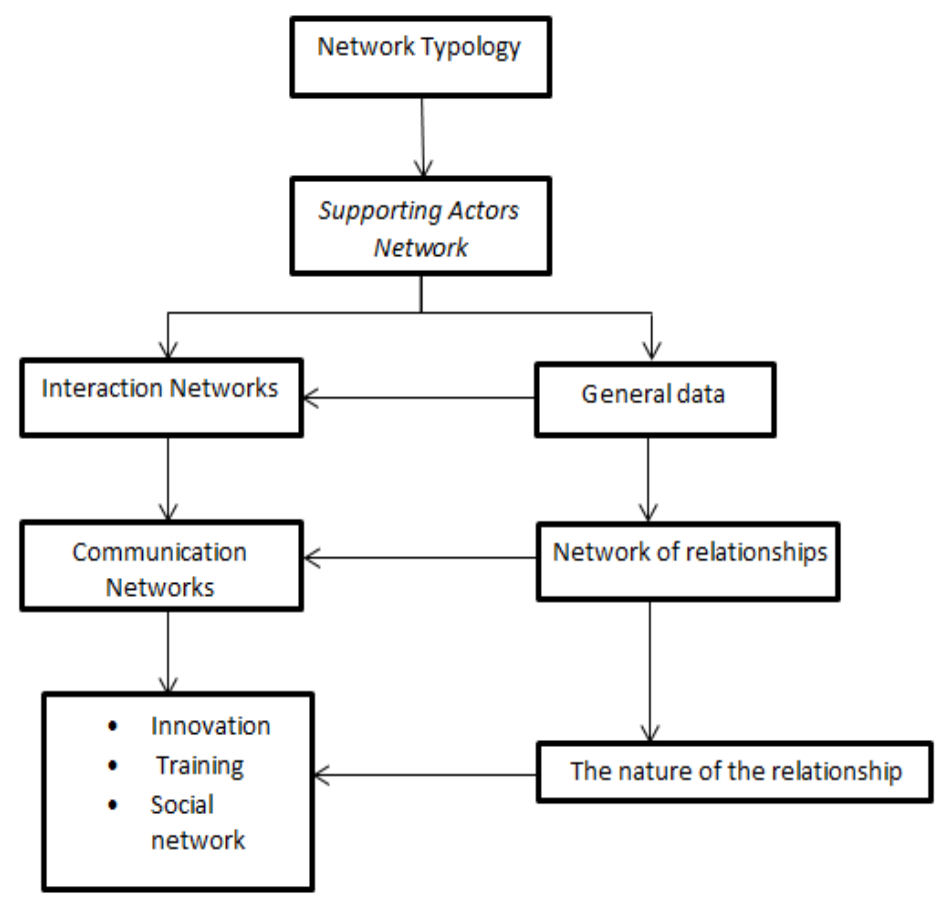

Fig 1. Network Topology

http://ijstm.inarah.co.id 


\section{RESULT AND DISCUSSION}

Data Crawling Results

Data crawling is carried out on Twitter social media for 5 days, from September 20th, 2020 to September 25th, 2020 using the Gephi programming application.

Table 2. Crawling Data

\begin{tabular}{|c|c|}
\hline $\begin{array}{c}\text { Driver Partner } \\
\text { Application }\end{array}$ & $\begin{array}{c}\text { Crawling } \\
\text { Tweets Results }\end{array}$ \\
\hline Gofood & 31,900 \\
\hline Grabfood & 17,440 \\
\hline Total & 49,340 \\
\hline
\end{tabular}

Table 1 shows that the tweets that have been crawled on user interactions on Twitter social media regarding the Gofood Food SME driver-partner application are as many as 31,900 tweets, while the interaction tweets regarding the Grabfood food driver-fgrye partner application are 17,440 tweets posted by actors. The total number of tweets posted by the actor during the 5 days regarding the driver partner application of home culinary entrepreneurs was as much 49,340 tweets.

Home Driver Partner Application Network

The results of social network modeling for user conversations about Gofood and Grabfood can be seen in Fig. 2.

Fig 2. Home Driver Partner Application Social Network 
The results of modeling that describe the social network formed from user interactions regarding Gofood and Grabfood can be seen in Fig 2. It can be seen in the picture nodes (dots) which represent actors/users and edges (lines) which symbolize the relationship between actors/users. After modeling the social network, an analysis of the properties of the network is carried out to determine the value of the social network.

Density Report is informed as below:

a. Parameters:

Network Interpretation: directed

b. Results (see Size Distribution):

Density: 0.001

Inclusiveness Report is informed as below:

a. Parameters:

Network Interpretation: directed

b. Results:

Number of Weakly Connected Components: 166 dots (see out-Degree Distribution)

Number of Strongly Connected Components: 1570 dots (see in-Degree Dsitribution)

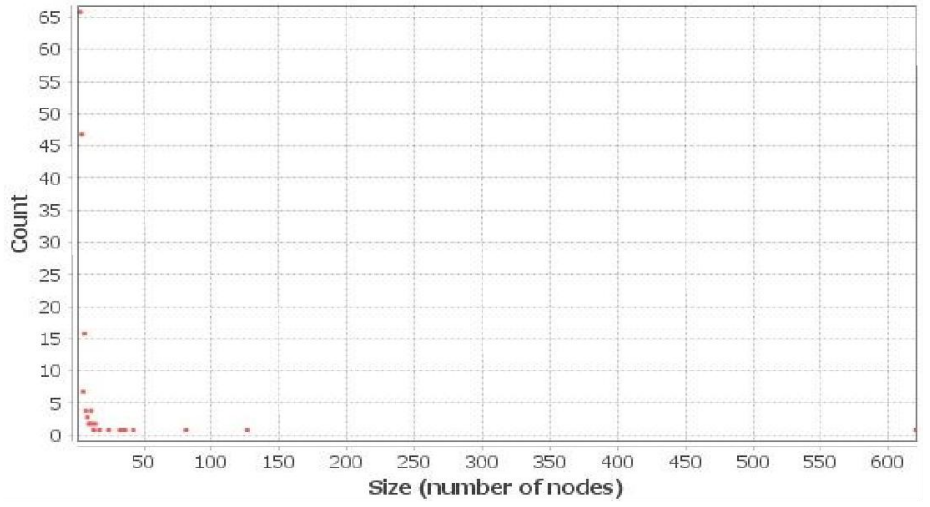

Fig 3. Size Distribution

c. Average Degree: 1.502 (see degree distribution)

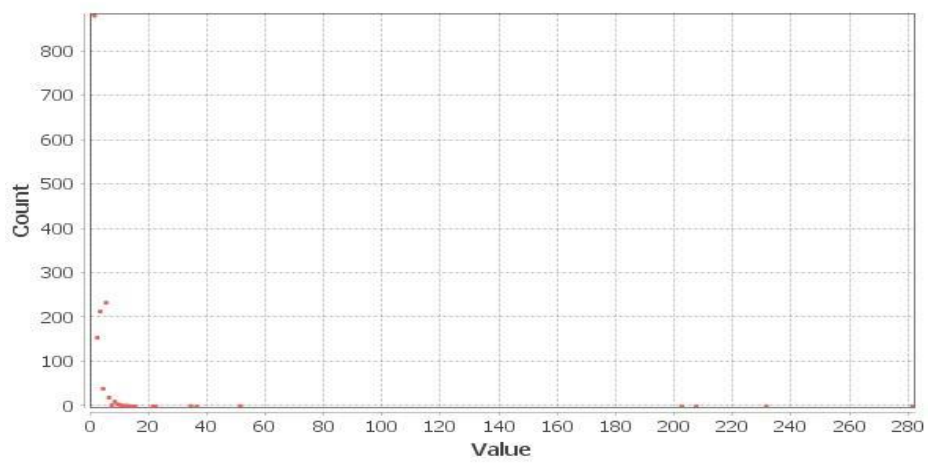

http://ijstm.inarah.co.id 
Fig 4. Degree Distribution

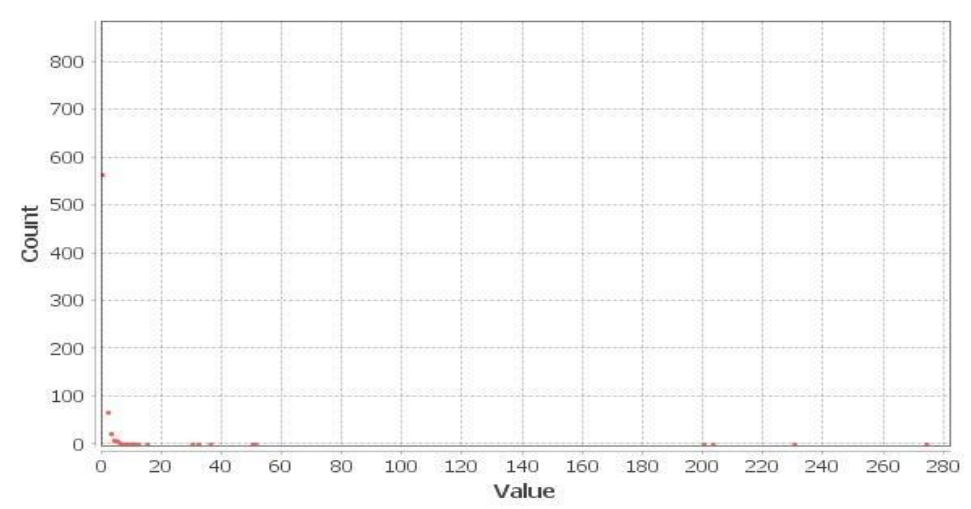

Fig 5. In-Degree Distribution

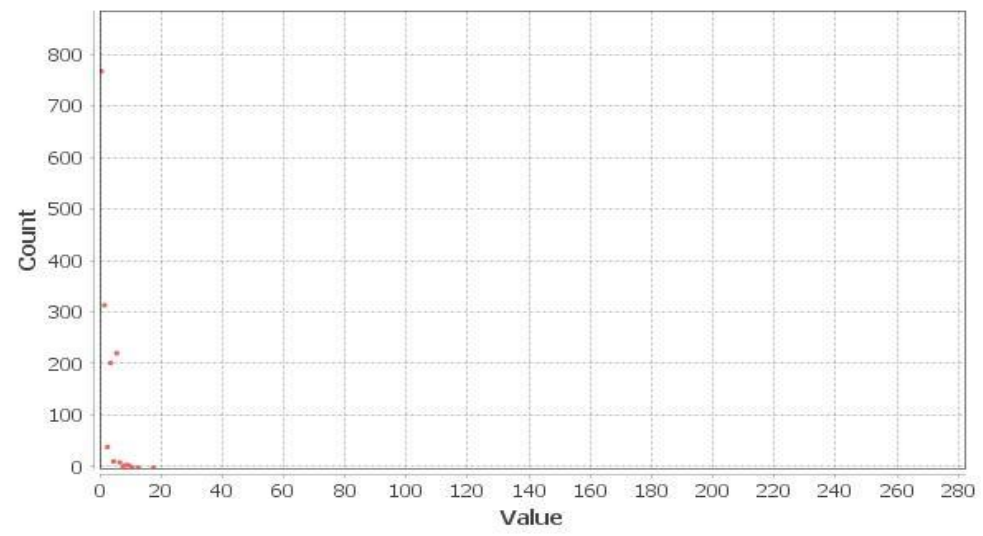

Fig 6. Out-Degree Distribution

Clustering Coefficient Metric Report as below:

a. Parameters:

Network Interpretation: undirected

b. Results (see Clustering Coefficient Distribution):

Average Clustering Coefficient: 0.295

Total triangles: 1154 dots

The Average Clustering Coefficient is the mean value of individual coefficients.

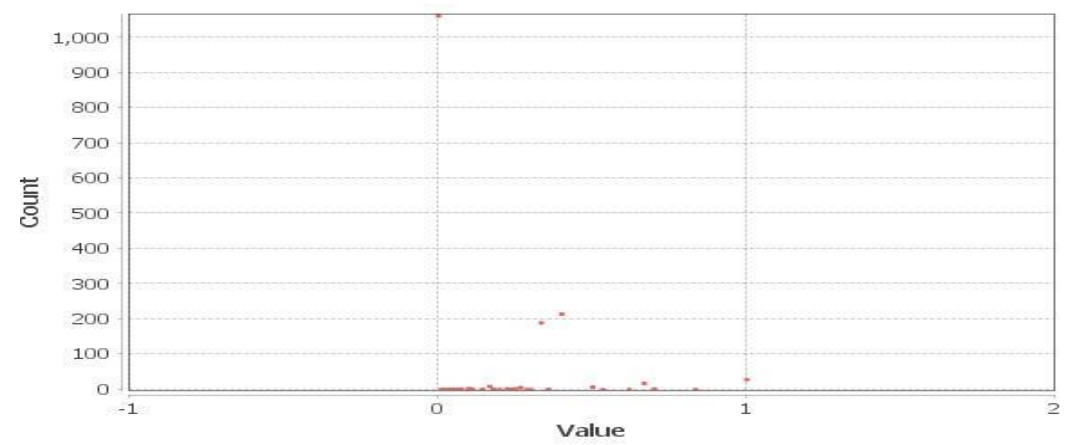

Fig 7. Clustering Coefficient Distribution

http://ijstm.inarah.co.id 
International Journal Of Science, Technology \& Management

Network Centralization Report

a. Parameters:

Network Interpretation: directed

b. Results:

Diameter: 6 (see Eccentricity Distribution)

Radius: 0 (see Betweenness Centrality Distribution)

Average Path length: 1.9739891836209116 (see Harmonic Closeness Centrality Distribution)

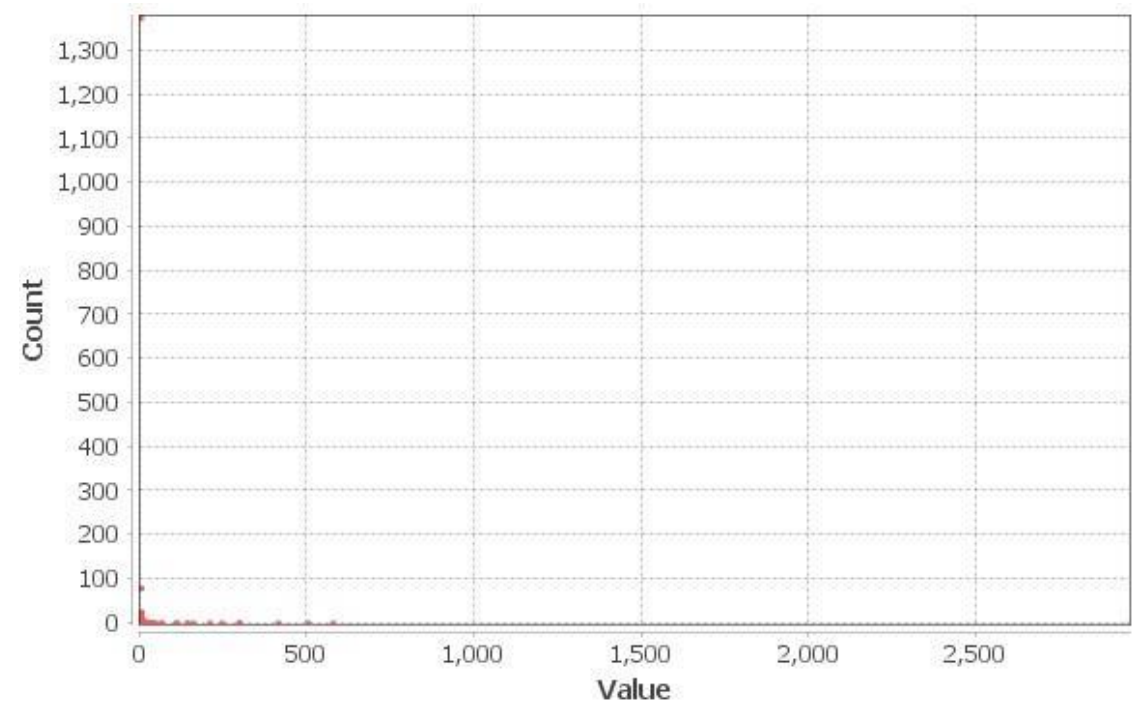

Fig 8. Betweenness Centrality Distribution

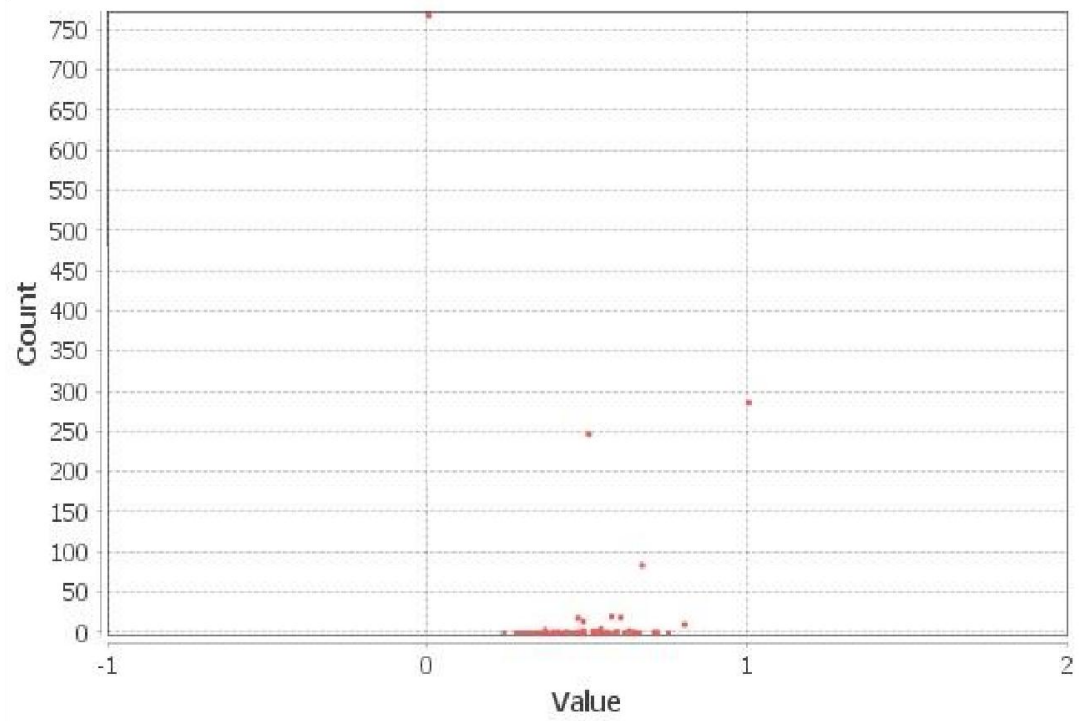

Fig 9. Closeness Centrality Distribution

http://ijstm.inarah.co.id 
International Journal Of Science, Technology \& Management

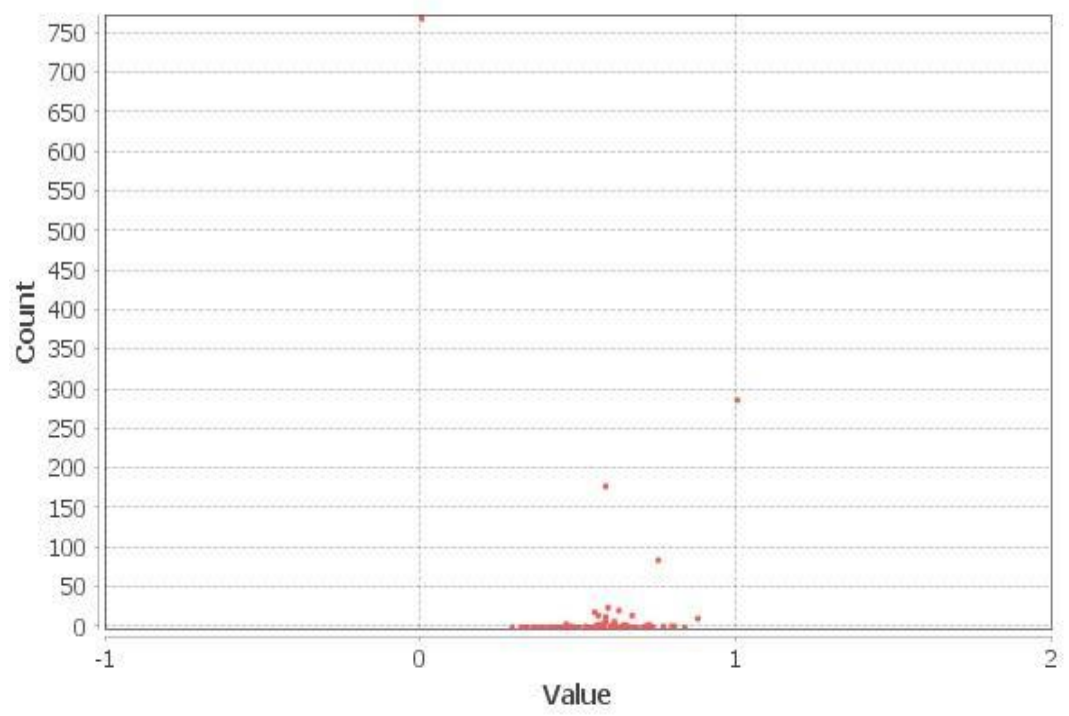

Fig 10. Harmonic Closeness Centrality Distribution

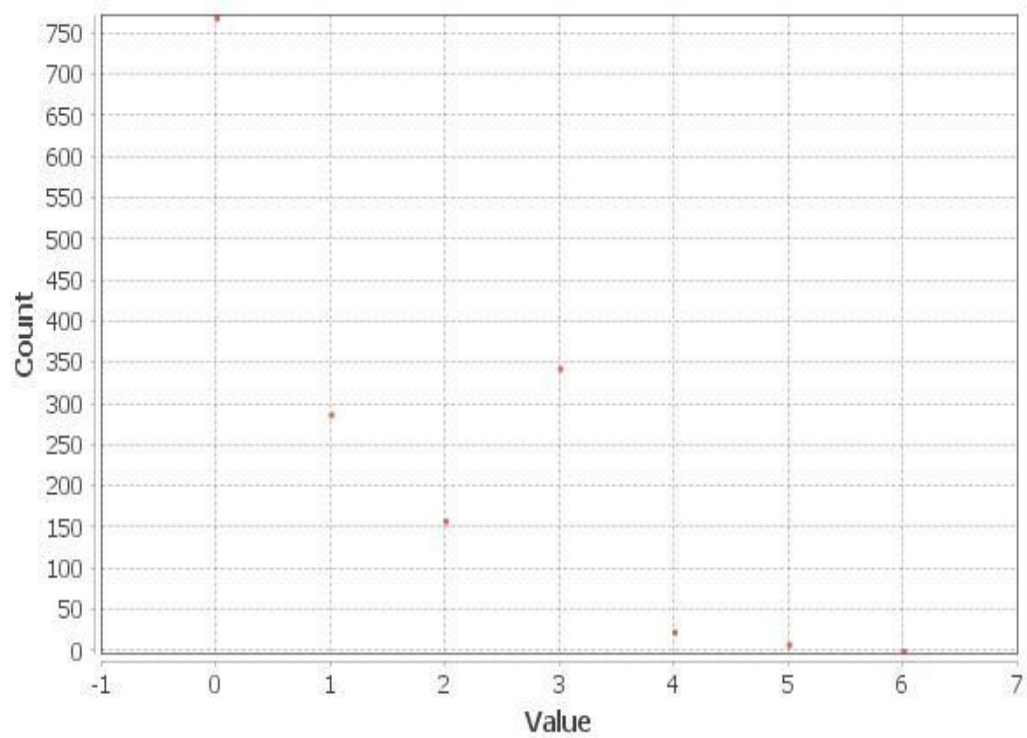

Fig 11. Eccentricity Distribution

PageRank Report as below (see PageRank Distribution):

a. Parameters:

Epsilon $=0.001$

b. Results:

Probability $=0.85$ 


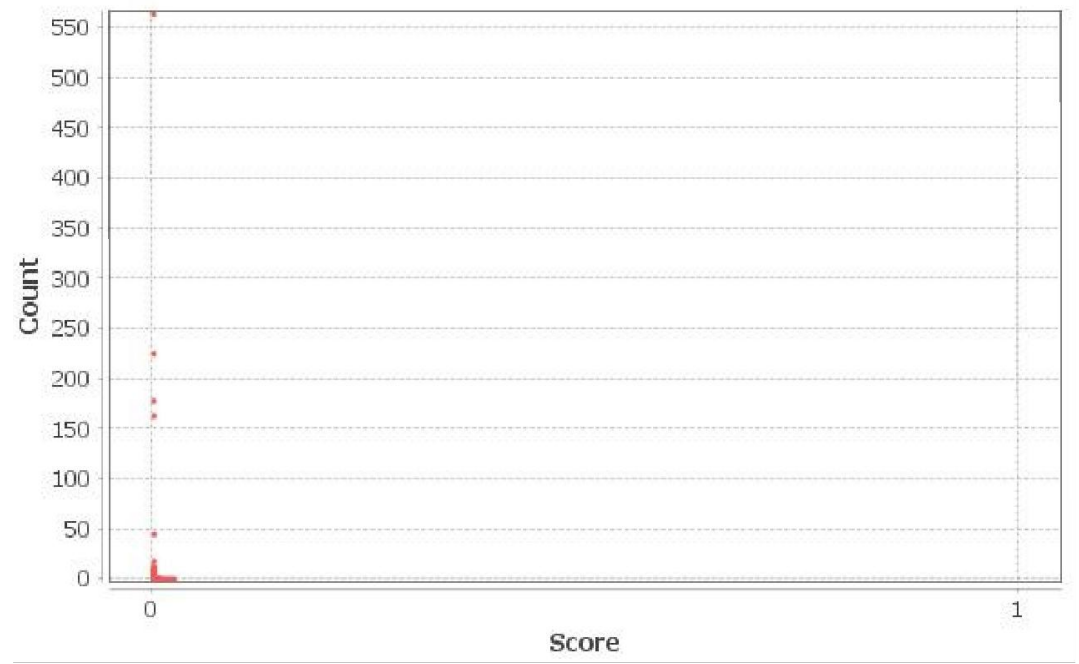

Fig 12. PageRank Distribution

In Table 3, an assessment can be made related to social networks formed from the Gofood driver-partner applications in social networks. Density indicates the ratio of the existing bonds with all possible connections, the smaller the bond, the stronger the bond, which is indicated by 0.001 , which means that the connection is stronger.

Table 3. Gofood's Social Property Results

\begin{tabular}{|c|l|c|}
\hline No & Network Properties & Result \\
\hline 1 & Density & 0.001 \\
\hline 2 & Inclusiveness & $\begin{array}{l}\text { Weakly Connected Components: } 166 \\
\text { Strongly Connected Components: } 1570\end{array}$ \\
\hline 3 & Average Degree & 1.502 \\
\hline 4 & Clustering Coefficient & 0.295 \\
\hline 5 & Network Centralization & 1.9739891836209116 \\
\hline 6 & PageRank & 0.85 \\
\hline
\end{tabular}

Inclusiveness is the number of connected points expressed as a proportion of the total number of points, in this study the weakest was 166 points, and the strongest was 1570 points. The average degree in this study was 1,502. The number of links associated with each actor (nodes) in social networks, the more links (edges) that connect between nodes, the faster and easier information dissemination will be.

The clustering coefficient is 0.295 , which means that the smaller the actors (nodes) in a network tend to group. Network Centralization of 1.973, which means the length of 6 links between nodes is short in diameter. PageRank 0.85, which 
International Journal Of Science, Technology \& Management

means close to 0 or the absence of PageRank implies that communication and exchange between component members do not depend on one member/actor.

\section{CONCLUSION}

It can be concluded that through the analysis of the Driver Partner Application network, home-based culinary entrepreneurs can collaborate with driver-partner applications to increase sales, brand awareness, and impressions to consumers. Looking at the data analysis above, consumers still use the driver-partner application as an option in buying food (Gofood and Grabfood). Meanwhile, social becomes one of the channels in promotion, catalogs, and introducing culinary products. In this study, the researchers gave suggestions to home-based culinary entrepreneurs in order to increase post-pandemic sales. This is believed to increase learning in innovation at SME, which of course will support creativity and technological change [11], such as omnichannel ecosystem [12]. The innovation that needs to be done is innovation in the food and beverage menu, including promotional content. It is also suggested that it is necessary to develop theirselves for digital marketing training and an omnichannel ecosystem.

\section{ACKNOWLEDGMENTS}

The authors acknowledge the financial support from the Ministry of Research and Technology/National Research and Innovation Agency, PDP program Fund 20192020.

\section{REFERENCES}

[1] T. Lubis, Junaidi, Utilization of Information Technology in Micro, Small and Medium Enterprises in Jambi City, Journal of Regional Financing and Development Perspectives, 3:3, 2016, pp. 163-174.

[2] M. Saifullah, Innovation in the Use of Information Technology: Adoption of Innovations in the Utilization of Information Technology at Kampung Sepatu MSMEs in Osowilangon Pond, Benowo District, Surabaya City, Public Management Fund Policy, 3:2, 2015, pp. 132- 141.

[3] C. F. Arifianto, A. Susilo, Mutawali, R. Tajuddien, F. Romdonih, Peningkatan Kapabilitas Pemanfaatan Ponsel Pintar pada Generasi Milenial dalam Berwirausaha di Era Disrupsi,

JURPIKAT, 1: 2, 2020, pp. 97-109

[4] C. Stephanie, Satu Dekade Beroperasi, Gojek Punya 2 Juta Mitra Pengemudi di Asia Tenggara, Kompas.com, 12 November 2020, https://tekno.kompas.com/read/2020/11/12/18090947/satu-dekade-beroperasi-gojekpunya-2-juta-mitra-pengemudi-di-asia-tenggara?page=all

[5] C. Akbar, Kemenperin Proyeksi Industri Makanan Minuman Tumbuh 3 Persen Akhir 2020, Jika..., Tempo.co, 11 Agustus 2020, 
International Journal Of Science, Technology \& Management

https://bisnis.tempo.co/read/1374738/kemenperin-proyeksi-industri-makanan-minumantumbuh-3-persen-akhir-2020-jika/full\&view $=$ ok

[6] S. S. Utami, The Influence of Information Technology in Business Development, Journal of Accounting and Technology Systems, 8: 1, 2010, pp. 61-67.

[7] H. Almubaraki, M. Aruna, Technology Innovation for SME Growth: A Perception for The Emerging Economy, Journal of Economics and Sustainable Development, 4: 3, 2013, pp. 156-162.

[8] A. Purwanto, Potret dan Tantangan UMKM di Indonesia, Kompas.id, 16 September 2020, https://kompaspedia.kompas.id/baca/paparan-topik/potret-dan-tantangan-umkm-diindonesia

[9] E. Suryowati, Akumindo Yakin Kontribusi UMKM Tahun ini Capai Rp 2.394,5 Triliun, Jawapos.com, 2020, https://www.jawapos.com/ekonomi/16/01/2020/akumindo-yakinkontribusi-umkm-tahun-ini-capai-rp-2-3945-triliun/

[10] N. Koçak, Social Networks and Social Network Analysis, International Journal of Business and Social Science, 5:2, 2014, pp. 126-135.

[11] S. Didonet, G. Diaz-Villavicencio, Innovation management in market-oriented SMEs: learning and internal arrangements for innovation, International Journal of Organizational Analysis, 28: 5, 2020.

[12] C. Varvello, The optimal omnichannel strategy for SMEs Apparel retailers Postgraduate Thesis, Universidade Católica Portuguesa, 2019. 